\title{
Seasonal Variation in Admission for Heart FAILURE, HYPERTENSION AND STROKE IN UYO, SOUTH-EASTERN NIGERIA
}

\author{
V. O. Ansa ${ }^{1}$, J.U. Ekott' ${ }^{2}$, I.O. Essien ${ }^{2}$, and E.O. Bassey ${ }^{2}$ \\ ${ }^{1}$ Department of Medicine, University of Calabar Teaching Hospital, Calabar, Nigeria \\ ${ }^{2}$ Department of Medicine, University of Uyo Teaching Hospital, Uyo, Nigeria \\ Reprint requests to: Dr. V.O. Ansa, P.O. Box 3105, Calabar, Nigeria. E-mail: vic ansa@yahoo.com
}

\begin{abstract}
Background: Seasonal variation in hospitalization for cardiovascular disease has been described in the temperate regions of the world as well as in Northern Nigeria. Increase admission rates during the cold seasons have been reported in these areas. No studies have been done in Southern Nigeria. This study is thus aimed at describing the seasonal variation in admissions for heart failure, uncontrolled hypertension and hypertension related-stroke in Southern Nigeria.

Methods: Hospital records of patients admitted to the medical wards of the University of Uyo Hospital (UUTH) with heart failure of all causes, uncontrolled hypertension and hypertension - related stroke (Cerebrovascular accident) between January 1998 and December 2001 were used. Epi-Info 2002 software was used to analyze data.

Results: Of the 3500 patients admitted during the study period 542 (15.3\%) were on account of heart failure, uncontrolled hypertension and hypertension related cerebrovascular accident (CVA). The mean age of patients was $52 \pm 12.8$ years. The average monthly admission was eleven (11). More admissions were recorded in the rainy (cold) season than in the dry (hot) season. The observed difference was however statistically significant only for heart failure and uncontrolled hypertension $(P<.05)$.

Conclusion: Admissions for heart failure and uncontrolled hypertension are therefore more during the wet (cold) season in southern Nigeria. This may be attributed to the high default rate to follow up visit in this season when agricultural activity is intense and less attention given to medical care. This leads to poor compliance to medications and clinical deterioration. The already bad road network both in rural and urban centers also become worse at this time making access to medical care difficult. Facilities and measures should thus be put in place to provide adequate medical care for these patients during that period of the year.
\end{abstract}

Key words: Admissions, seasonal variation, cardiovascular diseases

\footnotetext{
Résumé

Culture générale: des variations saisonnières dans l'hospitalisation pour les maladies cardiovascule ont été signale dans les régions tempères du monde aussi bien que dans le nord du Nigeria. On a note une augmentation d'hospitalisation dans ces régions pendant les saisons de pluies. Aucune recherche n'a été faite au sud du Nigeria. Le but de cette étude est donc de signaler les variations saisonnières dans l'hospitalisation des cas comme ; insuffisance cardiaque, l'hypertension non maîtrisée et l'attaque d'apoplexie lié a l'hypertension dans le sud du Nigeria.

Modalité: on s'est servi des registres d'hôpital pour surveiller les malades hospitalisés au centre hospitalier universitaire d'Uyo pour les cas comme: insuffisance cardiaque de toute sortes,
} 
l'hypertension non maîtrisée et l'attaque d'apoplexie liée a l'hypertension (des accidents cerebrovasculaire) entre Janvier 1988 et décembre 2001. On a utilisé le logiciel Epi-info 2002 pour analyser les données.

Résultat: parmi les 3500 malades hospitalisés pendant la période des recherches, 542 d'eux (5.3\%) étaient a cause de l'insuffisance cardiaque, l'hypertension non maîtrisée et des accidents cerebrovasculaire liés a l'hypertension (ACV). L'age moyen des malades était $52+12.8$ ans ; et I'hospitalisation moyenne par mensualités était onze (11). On a attesté beaucoup d'hospitalisation $\mathrm{s}$ pendant la saison de pluies que pendant la saison sèche. Pourtant, la différence remarquée était statistiquement significatif, uniquement pour le cas d'insuffisance cardiaque et l'hypertension non maîtrisée ( $\left.p^{\wedge} 0.05\right)$.

Conclusion: donc, dans le sud du Nigeria, il y a plus d'hospitalisation pendant la saison de pluies, pour des cas comme ; insuffisance cardiaque et l'hypertension non maîtrisée. On attribue cette situation a un pourcentage élevé du manquement des soins post-hospitaliers ; surtout dans une saison ôu l'activité agricole est intensive et ôu il y a moins de soins médicaux. Cela entraîne la mauvaise conformité à la médication et une détérioration clinique. Le réseau routier dans les centres urbains et ruraux qui est déjà mauvais, devient encore pire et par conséquent, c'est difficile d'avoir accès au soin médicaux. On doit mettre a exécution des mesures et des equipments pour assurer aux malades de bonnes guérison pendant cette période d'année

Mots clés: variation saisonnière, cardiovascule, hospitalisation

\section{Introduction}

Heart failure is a pathophysiological state in which there is impairment in the pump function such that the heart fails to maintain the circulation adequately. ${ }^{1}$ In nearly all regions in the world, heart failure is both common and on the rise. ${ }^{2,3}$ In Africa, at least $3 \%-7 \%$ of all hospital admissions are for heart failure. ${ }^{4}$ The cause of heart failure varies around the world, in sub-Saharan Africa including Nigeria, rheumatic heart disease is still a common cause especially in the young but hypertension is the major cause in the large cities. ${ }^{5}$ Other causes include dilated cardiomyopathy and its variant peripartum cardiomyopathy.

Hypertension is largely asymptomatic and owing to the profound lack of awareness and poor perception of the disease, most Nigerian hypertensives frequently present in hospital only when complications occur or severely elevated blood pressure values incidentally recorded.

Studies have demonstrated seasonal variation in the hospitalization for heart failure in the temperate climate. ${ }^{6-8}$ More admissions were found to occur in the cold (winter) season. A study in Northern Nigeria showed seasonal variation in hospitalization of cases of heart failure due to peripartum cardiomyopathy. ${ }^{9}$

Seasonal variation in arterial blood pressure has also been demonstrated among hypertensive patients in the temperate climate. ${ }^{10} \mathrm{~A}$ study from Northern Nigeria clearly showed an increase in hospitalization for hypertension-related morbidities in Sokoto during the cold seasons. ${ }^{11}$ In the southern states there are two distinct seasons, Wet (Cold) March to October and Dry (Hot) - November to February..$^{12}$ Maximum temperature is between $31^{\circ} \mathrm{C}$ and $32^{\circ} \mathrm{C}$ with occasional extremes of $33^{\circ} \mathrm{C}$ to $34^{\circ} \mathrm{C}$ during the dry season. Minimum temperature ranges from $21^{\circ} \mathrm{C}$ to $23^{\circ} \mathrm{C}$ although sometimes figures as low as $18^{\circ} \mathrm{C}$ may be recorded in the wet season.

This study is aimed at describing the seasonal variation in admissions for heart failure, hypertension and hypertension related stroke in a tertiary health institution in Southern Nigeria.

\section{Subjects and Methods}

Hospital records of patients admitted into the medical wards of the University of Uyo Teaching Hospital, Uyo (UUTH) with heart failure of all causes, uncontrolled hypertension and hypertension relatedstroke (cerebrovascular accident) between January 1998 and December, 2001 were examined.

Information extracted included age, sex, diagnosis and month of admission. The diagnosis of heart failure was made on the basis of clinical features and the specific etiological factors identified using hematological parameters, chest radiography, electrocardiography and 2D/M-mode echocardiography. Hypertension was diagnosed using the WHO/ISH criteria. $^{13}$ A blood pressure of $\geq$ $140 \mathrm{mmHg}$ systolic and or $90 \mathrm{mmHg}$ diastolic was diagnostic. Stroke was diagnosed on the basis of clinical features only.

\section{Exclusion criteria:}

1. Cases of acute renal failure and chronic kidney disease.

2. Cases of suspected coronary artery disease.

Data were analyzed in groups, means and percentages. The student $t$ test was used to assess difference between groups. The level of statistical significance was fixed at $P<.05$. 


\section{Results}

A total of 3550 patients were admitted into the medical wards during the study period. Of these $542(15.3 \%)$ were on account of heart failure of various causes, uncontrolled hypertension and hypertension related stroke. A breakdown showed that Heart failure accounted for 245(6.9\%), uncontrolled hypertension 195(5.5\%) and stroke (cerebrovascular accident) 102(2.9\%).

The study population comprised 300 males and 242 females. The ratio was approximately 1.2:1. Age range $18-94$ years, with mean age of $52 \pm 12.8$ years.

Two hundred and forty five cases of heart failure (45.2\%) were admitted, of these 90 (36.7\%) were due to hypertension while $83(33.9 \%)$ were due to dilated cardiomyopathy. Anaemia and rheumatic heart disease accounted for $40(16.3 \%)$ and 32 (13.1\%) respectively.

One hundred and ninety five (36.0\%) subjects were admitted for uncontrolled elevated blood pressure alone while $102(18.8 \%)$ cases of cerebrovascular accident due to hypertension were admitted during the study period.

The monthly distribution of admissions is shown in Figure 1. Monthly admission ranged from 5 to 21 with a mean of 11 .

Figure 2 illustrates the relationship between admission and the different climatic conditions. More admissions took place in the wet (cold) season than in the dry (hot) season.

Table 1 shows comparison of admissions in the wet (cold) and dry (hot) seasons. It shows that even though there were more admissions during the wet (cold) season, the observed difference was only significant for heart failure and uncontrolled hypertension $(P<.05)$ but not for stroke (cerebrovascular accident).

\section{Discussion}

Several studies on seasonal variation in heart failure hospitalization carried out in the temperate countries $^{6-8}$ have shown an increase in admission during the winter (cold) season and a decline in summer (warm) season.

Increase morbidity and hospitalization during cold season (Rainy/wet and Harmattan) due to heart failure caused by dialed cardiomyopathy as well as hypertension-related morbidities have been documented among Nigerians in the Northern part of Nigeria., ${ }^{9,11}$

This study from the southern part of Nigeria has demonstrated significant seasonal variation in hospitalization for heart failure and uncontrolled hypertension but not for cerebrovascular accident (stroke). Seasonal variation for stroke admissions has not been demonstrated here probably because of the small number of subjects with stroke recruited. Most patients with stroke do not get treatment in the hospital owing the traditional and spiritual beliefs that surround its etiology.

The variation noted is despite the fact that during the two major seasons in the south (Rainy and Dry) extremes of temperatures are not usually recorded. ${ }^{12}$ Minimum temperatures in the south even in the wet season ranges between $21^{\circ} \mathrm{C}$ to $23^{\circ} \mathrm{C}$ with small diurnal variation. In the Northern part and plateau region, temperatures of between 9 and $18^{\circ} \mathrm{C}$ may be recorded in the cold season with large diurnal variation.

Figure 1. Bar chart showing monthly distribution of admissions

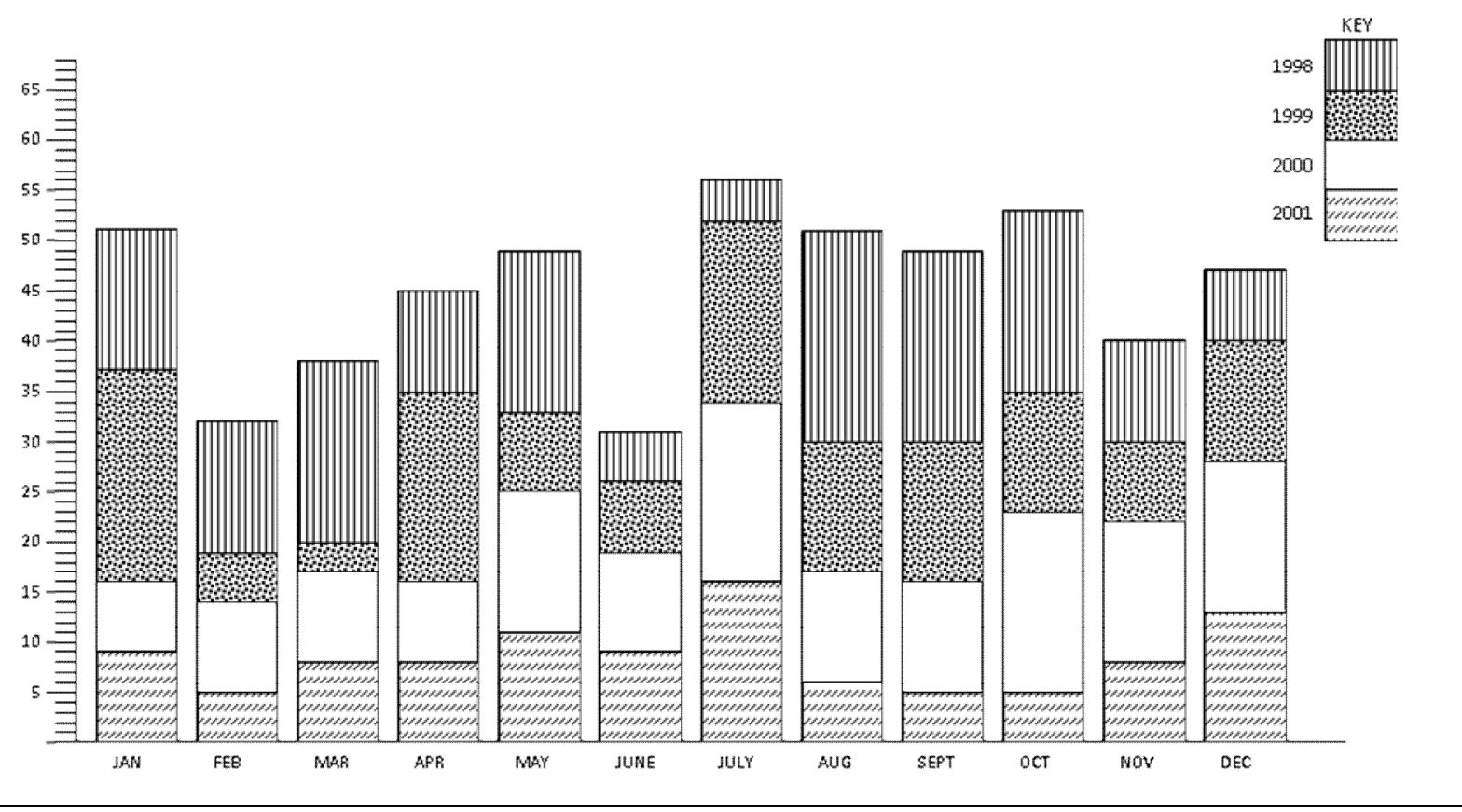


Figure 2. Seasonal variation in admissions

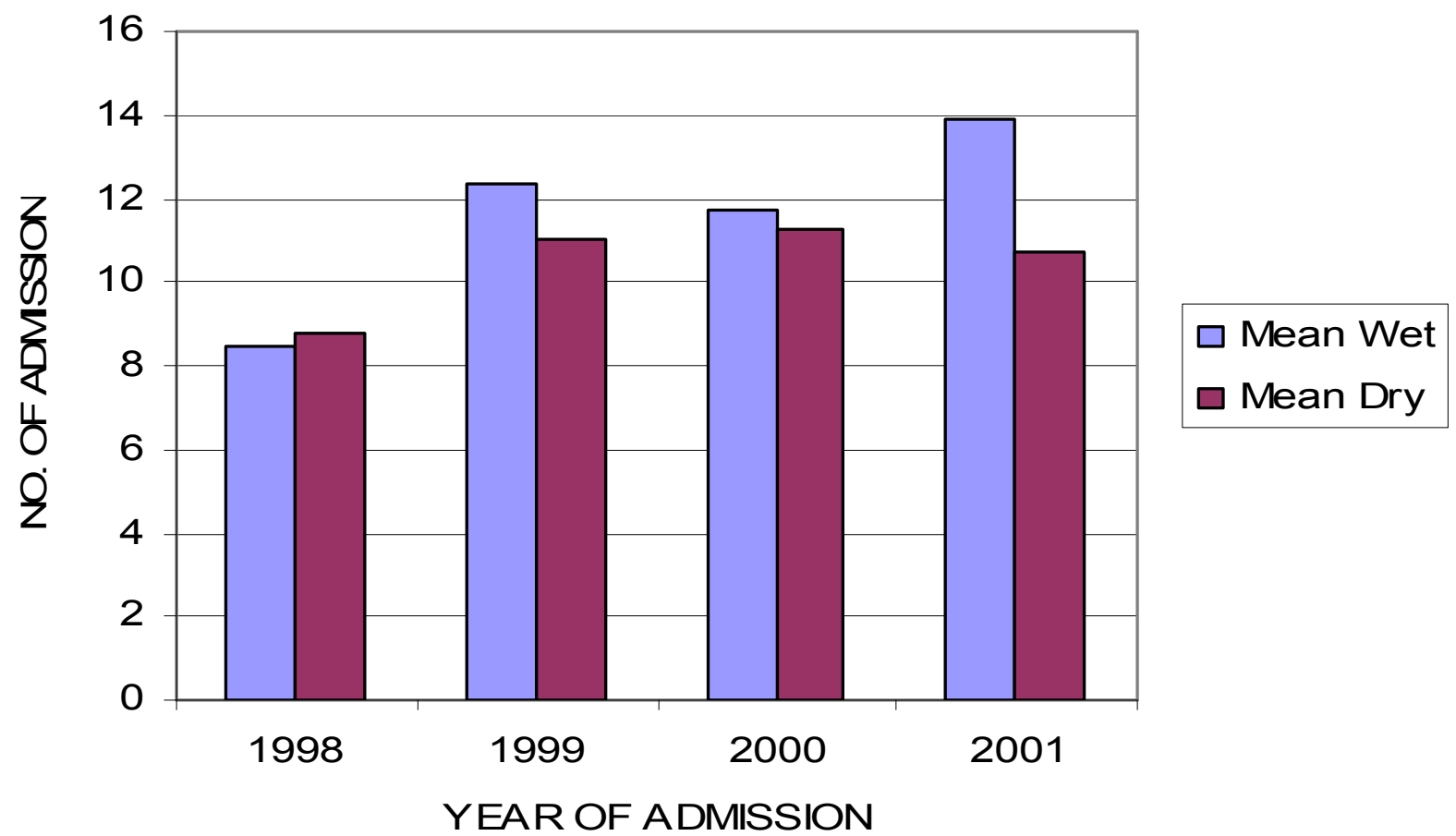

Table 1. Comparison of admissions for cardiovascular disease during the dry (hot) and wet (cold) seasons

\begin{tabular}{llll}
\hline Diagnosis & $\begin{array}{l}\text { Mean No. of } \\
\text { admissions }\end{array}$ & Calculated t value & p value \\
\hline $\begin{array}{l}\text { Heart failure } \\
\text { Dry (hot) season } \\
\text { Wet (cold) season }\end{array}$ & $\begin{array}{l}21.0 \pm 3.0 \\
\text { Hypertension }\end{array}$ & $-3.219 \pm 13.0$ & $0.049^{*}$ \\
$\begin{array}{l}\text { Dry (hot) season } \\
\text { Wet (cold) season }\end{array}$ & $12.0 \pm 5.0$ & -3.354 & $0.038^{*}$ \\
$\begin{array}{l}\text { Cerebrovascular accident } \\
\text { Dry (hot) season }\end{array}$ & $37.0 \pm 12.0$ & & \\
$\quad$ Wet (cold) season & $9.0 \pm 1.0$ & -2.287 & 0.106 \\
*Statistically significant & $17.0 \pm 8.0$ & &
\end{tabular}

The findings in this study may be explained by the fact that temperatures recorded in the south during the cold (wet) season are still low enough to trigger the cold induced changes in the cardiovascular system that would increase morbidity and thus hospitalization. These changes include increase in blood pressure consequent upon the thermoregulatory vasoconstriction. This is as a result of increase adrenaline and nor-adrenaline levels as well as an increase in peripheral resistance. ${ }^{13,14}$ Peripheral vasoconstriction induced by cold may also cause acute pulmonary edema by overloading the left ventricle particularly in those with hypertension. ${ }^{14}$ Modification of total extracellular volume is another mechanism. When temperatures decrease, loss of water by transpiration and perspiration decrease. These appear to be more important mechanisms of water loss than urine in patients with renal diseases and heart failure. Thus transpiration and perspiration may influence extracellular volume homeostasis in these patients than in normal subjects. ${ }^{15}$

Hospitalization for heart failure and hypertension therefore appears to more during the wet (cold) season in southern-Nigeria. Apart from the pathophysiological mechanisms outlined, the wet season is characterized by deterioration of the already bad road network which makes access to 
medical care difficult. Clinic appointments are not kept and compliance to medications poor resulting in clinical deterioration and complications warranting admission. Also, the intense agricultural activities during this season make patients and relatives not consider clinic visits a priority. Facilities and measures should then be put in place to receive and provide adequate medical care for these patients during this period of the year. A larger study involving more centers in the southern part of the country is indicated.

\section{References}

1. Colcucci W, Braunwald E. Pathophysiology of heart failure. In: Braunwald E (ed). A textbook of cardiovascular medicine. Saunders, Philadelphia, 2001; 503.

2. Oyoo GO, Ogola EN. Clinical and sociodemographic aspects of congestive heart failure patients at Kenyatta National Hospital, Nairobi. East Afr Med J. 1999;76:23-37.

3. Mc-Murray JV, Stewart S. Epidemiology, aetiology and prognosis of heart failure. Heart. 2000;83:596-602.

4. Mendex GF, Cowie MR. The epidemiological features of heart failure in developing countries: a review of literature. Int J Cardiol. 2000;93:1118.

5. Amoah AGB, Kallen G. Aetiology of heart failure as seen from a national cardiac referral centre in Africa. Cardiology. 2000;93:11-18.

6. Montes SH, Rey GG, Mediero DA, et al. Seasonal changes in hospitalization and mortality resulting from chronic heart failure in Vigo. An Med Interna. 2001;18:578-581.

7. Stewart S, Mc Intyre K, Capewell S, Mc Murray JJ. Heart failure in cold climate. Seasonal variation in hear failure related morbidity and mortality. Am J Cardiol. 2002;39:760-766.

8. Feldman DE, Plart $R$, Devy $V$, et al. Seasonal congestive heart failure mortality and hospitalization trends in Quebec 1990- 1998. Epidemiol Community Health. 2004;58:129-130.

9. Parry EHO, Davidson MD, Ladipo GA. Seasonal variation in cardiac failure in northern Nigeria. Lancet. 1997;1:1023-1025.

10. Brenman PJ, Greenberg G, Mall WE, Thompson SG. Seasonal variation in arterial blood pressure. BMJ. 1982;285:919-923.

11. Isezuo AS. Seasonal variation in hospitalization for hypertension-related morbidities in Sokoto, northwest Nigeria. Int J Circumpolar Health. 2003;62:393-409.

12. Clips focal point. Weather report. Nigeria Meteorological Agency, 2004.

13. Izzo JV, Larrabe PS, Sander E, Lillis LM. Haemodynamics of seasonal adaptation. Am J Hypertens. 1990;3:405-407.

14. Wilmhurst PT, Nuri M, Growther A, Webb Pepple MU. Cold induced pulmonary oedema in scuba divers and swimmers and subsequent development of hypertension. Lancet. 1989;1:62-65.

15. Argiles A, Mourad G, Mion C. Seasonal changes in blood pressure in patients with end-stage renal disease treated with haemodialysis. N Engl J Med. 1998;339:1364-1370. 